\title{
Article \\ Efficacy of Peat and Liquid Inoculant Formulations of Bradyrhizobium japonicum Strain WB74 on Growth, Yield and Nitrogen Concentration of Soybean (Glycine max L.)
}

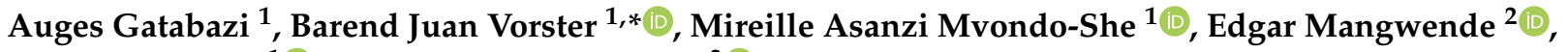 \\ Robert Mangani ${ }^{1}\left(\mathbb{D}\right.$ ) and Ahmed Idris Hassen ${ }^{3}(\mathbb{D}$ \\ 1 Department of Plant and Soil Sciences, University of Pretoria, Private Bag X21, Hatfield, \\ Pretoria 0002, South Africa; auges2012@gmail.com (A.G.); mnafabuanga@yahoo.fr (M.A.M.-S.); \\ manganirob@gmail.com (R.M.) \\ 2 School of Natural Resource Management, Nelson Mandela University, George 6529, South Africa; \\ edgarmangwende@gmail.com \\ 3 Agricultural Research Council-Plant Health and Protection Private Bag X134, Queenwood, \\ Pretoria 0121, South Africa; HassenA@arc.agric.za \\ * Correspondence: juan.vorster@fabi.up.ac.za; Tel.: +27-124-205-277
}

\section{check for} updates

Citation: Gatabazi, A.; Vorster, B.J.; Mvondo-She, M.A.; Mangwende, E.; Mangani, R.; Hassen, A.I. Efficacy of Peat and Liquid Inoculant

Formulations of Bradyrhizobium japonicum Strain WB74 on Growth, Yield and Nitrogen Concentration of Soybean (Glycine max L.). Nitrogen 2021, 2, 332-346. https://doi.org/ $10.3390 /$ nitrogen 2030023

Academic Editor: Germán Tortosa

Received: 15 June 2021

Accepted: 22 July 2021

Published: 27 July 2021

Publisher's Note: MDPI stays neutra with regard to jurisdictional claims in published maps and institutional affiliations.

Copyright: (c) 2021 by the authors. Licensee MDPI, Basel, Switzerland. This article is an open access article distributed under the terms and conditions of the Creative Commons Attribution (CC BY) license (https:// creativecommons.org/licenses/by/ $4.0 /)$.

\begin{abstract}
South African soils generally lack native Bradyrhizobium strains that nodulate and fix atmospheric nitrogen $\left(\mathrm{N}_{2}\right)$ in soybeans (Glycine max L.). It is therefore very important to inoculate soybeans with products that contain effective Bradyrhizobium strains as active ingredients. In this study, a field experiment was conducted on two bioclimatic zones in South Africa during the 2019/2020 season to assess the effect of Bradyrhizobium japonicum strain WB74 inoculant formulation on nitrogen fixation, growth and yield improvement in soybeans. The first bioclimatic zone was characterized by a sandy clay loam soil, whereas the second bioclimatic zone has a sandy loam soil. The results showed that inoculation of soybeans with both peat and liquid formulations of Bradyrhizobium japonicum WB74 increased nitrogen uptake, which resulted in yield increase. The amount of $\mathrm{N}$ fixed was measured as ${ }^{15} \mathrm{~N}$ isotopes and increased with all treatments compared to the uninoculated control in both liquid and peat inoculant formulations. In bioclimatic zone A, slightly better results were obtained using the liquid formulation $\left(1.79 \mathrm{t} \mathrm{ha}^{-1}\right.$ for liquid compared to $1.75 \mathrm{t} \mathrm{ha}^{-1}$ for peat treatments), while peat formulations performed better in bioclimatic zone $\mathrm{B}$ (1.75 $\mathrm{t} \mathrm{ha}^{-1}$ for peat compared to $1.71 \mathrm{tha}^{-1}$ for liquid treatments). In both areas higher yields were obtained with the formulations used in this study compared to the registered standards (treatment T3). The findings in this study provide vital information in the development and application of formulated microbial inoculants for sustainable agriculture in South Africa.
\end{abstract}

Keywords: Bradyrhizobium japonicum; inoculant; formulation; nodulation; nitrogen soybean

\section{Introduction}

Soybean (Glycine max L.) is one of the most important annual grain legumes in the world and is currently produced at a higher rate in the USA, Brazil, Argentina, China, and India [1]. According to a report by the FAO [2], United States Department of Agriculture (USDA) estimates that the World Soybean Production 2020/2021 will be 361.00 million metric tons [3]. In South Africa, soybean is an economically important crop with production of $65,000 \mathrm{t} \mathrm{y}^{-1}$ at a mean yield of $1377 \mathrm{~kg} \mathrm{ha}^{-1}$ [4]. Projections have shown that the amount of land allocated to commercial soybean production will increase in the coming decades when compared to the current production area [5]. This will be because of the everincreasing demand for the use of the crop for both human nutrition and as well as a feed an ever-increasing local industrial demand for soybeans for agro-processing [6]. Additionally, commercial farmers are becoming cognizant of the benefits of soybean in crop rotation systems with maize, thus contributing to its increase in production. [7]. 
The major focus in the coming decades would be on safe and eco-friendly methods by exploiting the benefits of micro-organisms in sustainable crop production such as soybean and other legumes crops. Bio-stimulants such as microorganisms, consist of diverse naturally occurring microbes whose inoculation to the soil ecosystem improve soil microbe's biodiversity, soil physicochemical properties, soil health, plant growth development and crop productivity [8]. They also play a role in increasing crop productivity through metabolic activities and enhance the nutrient uptake through nitrogen fixation, solubilizing nutrient and modifying hormonal status by inducing plant hormones biosynthesis such as auxins and cytokinin [9].

According to the report by Abaidoo et al. 2007 [10], the cost of chemical fertilizers is becoming un-affordable for the farmers of rain-fed areas in addition to creating soil and water hazards. Biological nitrogen fixation (BNF) is a characteristic of agricultural soil, which can support high soybean yields without application of inorganic nitrogen fertilizers. The benefit acquired from the use of rhizobium inoculants shows that farmers can save a lot of money by using effective inoculants on the farm. There is great need to supplement or substitute chemical fertilizers with organic manures or to explore biological means to improve the soil health [11].

The most important source of nitrogen fixation is derived from the activity of soil bacteria that absorb atmospheric $\mathrm{N}_{2}$ gas and convert it into ammonium [12]. The process of biological nitrogen fixation offers an economical attractive and ecological advantage by of reducing external nitrogen input and improving the quality and quantity of internal resources [12]. However, high yielding soybean requires large amounts of nitrogen. Plants are inhibited by low root zone temperatures. Nitrogen is one of the most abundant and major limiting factors of growth and production of crops, which can only be utilized by plants when it is reduced to ammonia by the process of nitrogen fixation [13]. It can either be reduced by chemical fixation through industrial production or by biological fixation through the enzymatic activities of microorganisms. Most plants utilize nitrogen in its ionic forms, ammonium $\left(\mathrm{NH}_{4}^{+}\right)$and nitrate $\left(\mathrm{NO}_{3}{ }^{-2}\right)$, from soil [14]. The use of a biological nitrogen-fixing (BNF) system is becoming increasingly important due to the significant increase of maintenance and promotion of sustainable agricultural production [15]. The least expensive source of $\mathrm{N}$ for soybeans is through the biological fixation of atmospheric $\mathrm{N}_{2}$ by the symbiotic association between the plant-root and soil bacteria belonging mainly to the genus Bradyrhizobium [1]. Rhizobia form active nodules that are responsible for the biological nitrogen fixation process of the legumes [16]. For nitrogen to be used by crops, it must be converted to the form of ammonium or nitrate ions. Microorganisms can improve plant growth, uptake, yield and quality [17-19]. This study aims to evaluate and compare the efficacy of liquid and powdered formulations of Bradyrhizobium japonicum strain WB74 inoculants on nodulation, nitrogen fixation as well as yield improvement of soybean upon inoculation.

\section{Matrials and Methods}

\subsection{Liquid and Peat Inoculant Preparation}

Bradyrhizobium japonicum strain WB74 was purchased from the Agricultural Research Council, Plant Health and Protection located at Roodeplaat (East), Pretoria (South Africa). Actively growing bacterial cultures on Yeast mannitol agar supplemented with congo red, a $10 \mathrm{~mL}$ inoculum was transferred in $750 \mathrm{~mL}$ Yeast Extract mannitol broth and shaken at 150 r.p.m. at $30^{\circ} \mathrm{C}$ for $3-5$ days until a concentration of $6.5 \times 10^{9}$ cells $/ \mathrm{mL}$ was reached. Yeast mannitol broth consists of $(\mathrm{g} / \mathrm{L}) 10.0$ mannitol, $0.5 \mathrm{~K}_{2} \mathrm{HPO}_{4}, 0.2 \mathrm{MgSO}_{4} \cdot 7 \mathrm{H}_{2} \mathrm{O}$, $0.1 \mathrm{NaCl}, 1.0$ yeast extract, 1.0 glucose, 0.5 arabinose, $200 \mathrm{mM} / \mathrm{L}$ FeEDTA and $4 \mathrm{~mL} / \mathrm{L}$ glycerol. A combination of additives was aseptically added and shaken at 150 r.p.m. at $30^{\circ} \mathrm{C}$ for $4 \mathrm{~h}$. This process delivers $1 \mathrm{~L}$ of liquid B. japonicum biofertilizer. However, the final formulation products were normalized and displayed as per $\mathrm{g} \mathrm{kg}^{-1}$ on the formulation. Yeast Mannitol Broth was prepared using the methods described by [20]. B. japonicum WB74 liquid inoculant contained $6.5 \times 10^{9}$ (6.5 billion) viable cells $\mathrm{g}^{-1}$ in the liquid inoculant. 
To prepare powdered formulation of the B. japonicum strain, WB74 peat moss was purchased from Hygrotech (Pty) Ltd. (Pretoria, South Africa). The B. japonicum culture was grown on yeast mannitol broth as described above and a $10 \mathrm{~mL}$ inoculum was transferred to $750 \mathrm{~mL}$ yeast extract mannitol broth and shaken at 150 r.p.m. at $30{ }^{\circ} \mathrm{C}$ for $3-5$ days until attaining a concentration of $6.5 \times 10^{9}$ cells $\mathrm{mL}^{-1}$. A combination of formulation additives was aseptically added, and then a $60 \mathrm{~mL}$ of yeast mannitol broth containing both $B$. japonicum and additives were homogenously mixed with $250 \mathrm{~g}$ sterile peat. The final formulation product is presented with normalized values, showing a breakdown of reagents $(\mathrm{g})$ required to make $1 \mathrm{~kg}$ of the formulation. B. japonicum WB74 peat inoculant contained $6.5 \times 10^{9}$ (6.5 billion) viable cells $\mathrm{g}^{-1}$. All chemicals obtained from Sigma-Aldrich (Gauteng, South Africa).

\subsection{Experimental Site}

The experiments were conducted on sites located in two different climatic zones according to the Koppen-Gieger climate classification [21]. The first site was located in Bronkhorspruit in the Gauteng province of South Africa, which is classified under a humid subtropical climate designated as C-wa (Bronkhorspruit, Gauteng, South Africa) located at $25^{\circ} 48^{\prime} 30^{\prime \prime} \mathrm{S}$ latitude and, $28^{\circ} 44^{\prime} 26^{\prime \prime} \mathrm{E}$. The soil at this site is sandy clay loam. The second site was located in Hartbeesfontein in North West province of South Africa and is classified as an arid climate denoted by BWwh. Rietfontein farm is located at $26^{\circ} 47^{\prime} 16^{\prime \prime} \mathrm{S}$ latitude and $26^{\circ} 53^{\prime} 59^{\prime \prime}$ E longitude with a sandy loam soil. The annual seasonal rainfall of the area is $670 \mathrm{~mm}$. The second bioclimatic zone is designated as Hartbeesfontein (North-West, South Africa) and the annual rainfall of the area is $612 \mathrm{~mm}$. The sites for the experiment have not been cultivated for the past five years. The annual seasonal rainfall was $612 \mathrm{~mm}$.

\subsection{Soil Analysis and Fertilizer Application}

Soil samples were randomly taken from depths of $0-40 \mathrm{~cm}$ to assess chemical and physical properties (Table 1). The soil of the experiment site was characterized as Hutton soil [22,23] form with a clay content of $36 \%$ at $0-40 \mathrm{~cm}$ soil depth (Table 1 ). No other fertilizer nutrients were added on both bioclimatic zones (Tables 2 and 3). Virgin soils not cultivated before were used and no $\mathrm{N}$ could be measured.

Table 1. Chemical and physical properties of different bioclimatic zones of the experiments at a depth of $0-60 \mathrm{~cm}$ of the soil horizon.

\begin{tabular}{|c|c|c|}
\hline Chemical and Physical Properties & Bioclimatic Zone 1 & Bioclimatic Zone 2 \\
\hline $\mathrm{pH}\left(\mathrm{H}_{2} \mathrm{O}\right)$ & 4.6 & 5.19 \\
\hline CEC $\left(\mathrm{cmol}(+) \mathrm{kg}^{-1}\right)$ & 3.2 & 2.3 \\
\hline Organic matter content (\%) & 1.3 & 0.8 \\
\hline P Bray1 (mg kg $\left.{ }^{-1}\right)$ & 6 & 10 \\
\hline $\mathrm{Ca}\left(\mathrm{mg} \mathrm{kg}^{-1}\right)$ & 410 & 278 \\
\hline $\mathrm{Na}\left(\mathrm{mg} \mathrm{kg}^{-1}\right)$ & 18 & 19 \\
\hline $\mathrm{K}\left(\mathrm{mg} \mathrm{kg}^{-1}\right)$ & 153 & 66 \\
\hline $\mathrm{Mg}\left(\mathrm{mg} \mathrm{kg}^{-1}\right)$ & 83 & 86 \\
\hline $\mathrm{S}\left(\mathrm{mg} \mathrm{kg}^{-1}\right)$ & 5 & 6.39 \\
\hline $\mathrm{N}\left(\mathrm{mg} \mathrm{kg}^{-1}\right)$ & 700 & 800 \\
\hline Density $\left(\mathrm{g} \mathrm{mL}^{-1}\right)$ & 1.1 & 1.2 \\
\hline Clay $(\%)$ & 22 & 18 \\
\hline Sand $(\%)$ & 68 & 73 \\
\hline Silt $(\%)$ & 10 & 9 \\
\hline
\end{tabular}

The cations are extracted using the 1M ammonium acetate solution, 1-10 soil solution mixture and analyzed on ICP OES. Carbon determined using the Walkley Black titration method. 
Table 2. Weather data for Bronkhorspruit/Gauteng during the year 2019/2020.

\begin{tabular}{ccccc}
\hline Month & Avg. $\mathbf{T}\left({ }^{\circ} \mathbf{C}\right)$ & $\begin{array}{c}\text { Minimum } \\
\text { Temp }\left({ }^{\circ} \mathbf{C}\right)\end{array}$ & $\begin{array}{c}\text { Maximum } \\
\text { Temp }\left({ }^{\circ} \mathbf{C}\right)\end{array}$ & Rainfall (mm) \\
\hline December & 21.9 & 15.9 & 28 & 98 \\
January & 21.3 & 14.9 & 27.8 & 129 \\
February & 21 & 14.6 & 27.5 & 88 \\
March & 19.7 & 13 & 26.5 & 76 \\
April & 16.8 & 9.3 & 24.3 & 44 \\
May & 13.3 & 4.8 & 21.8 & 75 \\
June & 10 & 1 & 19.1 & 7 \\
July & 10.1 & 1.1 & 19.2 & 6 \\
August & 12.9 & 3.7 & 22.1 & 20 \\
September & 16.5 & 7.9 & 25.2 & 68 \\
October & 19 & 11.4 & 26.7 & 112 \\
November & 20.1 & 13.3 & 26.9 & \\
\hline
\end{tabular}

Table 3. Weather data for Hartbeesfontein/North West during the year 2019/2020.

\begin{tabular}{ccccc}
\hline Month & Avg. $\mathbf{T}\left({ }^{\circ} \mathbf{C}\right)$ & $\begin{array}{c}\text { Minimum } \\
\text { Temp }\left({ }^{\circ} \mathbf{C}\right)\end{array}$ & $\begin{array}{c}\text { Maximum } \\
\text { Temp }\left({ }^{\circ} \mathbf{C}\right)\end{array}$ & Rainfall $\backslash(\mathbf{m m})$ \\
\hline December & 23.9 & 18.3 & 29.5 & 97 \\
January & 23.4 & 16.9 & 29.9 & 110 \\
February & 22.9 & 16.5 & 29.4 & 88 \\
March & 21.9 & 14.8 & 28.4 & 68 \\
April & 18.9 & 11.2 & 26.1 & 47 \\
May & 14.7 & 6.1 & 23.4 & 19 \\
June & 11.7 & 2.3 & 21.1 & 5 \\
July & 11.7 & 2.1 & 21.4 & 5 \\
August & 14.7 & 4.8 & 24.3 & 14 \\
September & 18.5 & 9.5 & 27.5 & 55 \\
October & 21.3 & 13.4 & 29.2 & 97 \\
November & 21.9 & 15 & 28.9 & \\
\hline
\end{tabular}

The recorded rainfall at the study sites in both soybean annual seasons.

Texture, (sand, silt and clay), determined using the Bouyoucous, hydrometer method, density with gravimetric method.

\subsection{Experimental Design and Treatment}

The field experiments were laid down in randomized complete block designs (RCBD) having four treatments and six replicates. The treatments used were Bradyrhizobium japonicum inoculant (Liquid) dosages T0 $=0 \mathrm{~mL}, \mathrm{~T} 1=150 \mathrm{~mL}, \mathrm{~T} 2=300 \mathrm{~mL}$ and $\mathrm{T} 3=150 \mathrm{~mL}$ for a reference registered standard (Rizoliq Soybean (L 8738), MBFi, South Africa)). For the peat inoculant, $\mathrm{T} 0=0 \mathrm{~g}, \mathrm{~T} 1=250 \mathrm{~g}, \mathrm{~T} 2=500 \mathrm{~g}$ and $\mathrm{T} 3=150 \mathrm{~mL}$, the same for liquid inoculant registered standard. Soybean cultivar LINK 6150 was planted in both bioclimatic zones. The field was ploughed and harrowed to a depth of $20 \mathrm{~cm}$ and divided into plots before planting. Each plot consisted of four soybean rows of $50 \mathrm{~m}$ long for both liquid and peat inoculant. The inter-row and intra-row spacing used were $0.71 \mathrm{~m}$ and $0.045 \mathrm{~m}$, respectively, giving a plant population of with 312,989 per hectare which gives $31.29 \mathrm{~m}^{2}$. The experiments were conducted during the summer cropping season of December 2019 to April 2020 for both locations. Planting date was carried out on 17th December 2019 for both sites and assessment date for growth parameters commenced from the 2nd February 2020, while harvest was done on 15th April 2020.

\subsection{Data Collection}

\subsubsection{Growth and Yield Parameters}

Growth parameter such as day of emergence were recorded from five to nine days after planting in both climatic zones conducted. The last recorded emergence was done 
when $80 \%$ of emerged were reached in all treated plots and replicates. Plant growth measurements, which includes plant height and root length were taken at flowering growth stage (R3). The two parameters were determined by randomly selecting and carefully uprooting twenty plants from each plot. Grain yield measurements were obtained from harvesting 20 plants that were selected randomly from the center of plots and the yield was expressed in tonnes per hectare $\left(\mathrm{t} . \mathrm{ha}^{-1}\right)$. Number and size of nodules were conducted by randomly sampling 20 plants on the center of the rows of each plot. This was done at mid-flowering by uprooting the whole plant carefully using a spade. The exercise of uprooting the plant was carefully done using a spade to avoid damage of nodules. The average number of nodules and size were determined from the above 20 plants and were counted and measured.

\subsubsection{Determination of Nitrogen Concentration with Dumas and Fixed Using the ${ }^{15} \mathrm{~N}$ Natural Abundance Technique}

Shoots of plant samples were collected at mid-flowering from each plot and oven dried at $70^{\circ} \mathrm{C}$ to a constant weight, ground and passed through a $1 \mathrm{~mm}$ sieve. Nitrogen concentration in both liquid and peat from leaves were analyzed by Dumas method. While nitrogen fixation with ${ }^{15} \mathrm{~N}$ isotope abundance technique was analyzed after the samples were mechanically homogenized prior to weighing. Aliquots of plants samples of approximately 1.0 to $1.2 \mathrm{mg}$ were weighted into tin capsules that have been pre-cleaned in toluene. Samples for isotopic analysis were replicated four times for each treatment. Then, samples were combusted at $1020^{\circ} \mathrm{C}$ using an elemental analyzer (Flash EA 1112 Series) coupled to a Delta V Plus stable light isotope ratio mass spectrometer via a ConFlo IV system (all equipment supplied by Thermo Fischer, Bremen, Germany), housed at the UP Stable Isotope Laboratory, Mammal Research Institute, University of Pretoria. Two laboratory running standards (Merck Gel: $\delta^{13} \mathrm{C}=-20.26 \%, \delta^{15} \mathrm{~N}=7.89 \%, \mathrm{C} \%=41.28$, $\mathrm{N} \%=15.29)$ ) (DL-Valine: $\delta^{13} \mathrm{C}=-10.57 \%, \delta^{15} \mathrm{~N}=-6.15 \%, \mathrm{C} \%=55.50, \mathrm{~N} \%=11.86$ ) and a blank sample were run after every 11 unknown samples. Data corrections were done using the values obtained for the Merck Gel and DL-Valine during each run.

All results were referenced to Vienna Pee-Dee Belemnite for carbon isotope values, and to air for nitrogen isotope values. Results are expressed in delta notation using a per mille scale using the standard equation:

$$
\delta \mathrm{X}(\%)=[(\text { Rsample }- \text { Rstandard }) / \text { Rstandard }-1]
$$

where $\mathrm{X}={ }^{15} \mathrm{~N}$ or ${ }^{13} \mathrm{C}$ and $\mathrm{R}$ represents ${ }^{15} \mathrm{~N} /{ }^{14} \mathrm{~N}$ or ${ }^{13} \mathrm{C} /{ }^{12} \mathrm{C}$, respectively.

The proportional contribution of BNF to legume growth $(\% \mathrm{Ndfa}=$ percentage of plant $\mathrm{N}$ derived from air) is therefore calculated from the fixed $\mathrm{N}$ abundance of the legume Non- $\mathrm{N}_{2}$-fixation reference plant as indicated in the following equation.

$$
\% N d f a=\frac{\left(\delta^{15} \text { Nref }-\delta^{15} \mathrm{~N} \text { fixing plant }\right)}{\delta^{15} \mathrm{Nref}-\mathrm{B}} \times 100
$$

where $\delta^{15} \mathrm{Nref}$ represents the level of $\delta^{15} \mathrm{~N}$ detected in a reference plant growing in the same soil at the same time as the test legume, $\delta^{15} \mathrm{~N}$ fixing plant is the ${ }^{15} \mathrm{~N}$ abundance of the legume and $\mathrm{B}$ is the ${ }^{15} \mathrm{~N}$ abundance $(\%)$ of the legume grown obtaining all its $\mathrm{N}$ from $\mathrm{N}_{2}$ fixation. The ${ }^{15} \mathrm{~N}$ content of the reference plant is assumed to provide an integrated determination of the $\delta^{15} \mathrm{~N}$ of the soil $\mathrm{N}$ available for plant growth over the duration of the study. It is also assumed that the $\delta^{15} \mathrm{~N}$ of this plant-available soil $\mathrm{N}$ pool is the same for the reference plant as for the legume. The greater the difference in $\delta^{15} \mathrm{~N}$ abundance between the $\mathrm{N}$ derived from the soil (as determined by the reference plant) and that of the air, the greater the accuracy of the subsequent estimates of $\% \mathrm{Ndfa}$. 
However, Determination of ${ }^{15} \mathrm{~N}$ fixed was calculated from the equation:

$$
N \text { fixed }\left(\mathrm{kg} \mathrm{ha}^{-1}\right)=\left(\frac{N d f a}{100}\right) \times N \% \times \text { Pant dry matter }
$$

$N d f a=$ percentage of plant $N$ derived from air; $N \%$ is the Nitrogen value from ${ }^{15} \mathrm{~N}$ isotope calculation; Plant dry matter is the mass of plant dry matter used. N-fixed per ha was estimated as product of fixed $\mathrm{N}$ in plant dry mass and plant density per ha. The plant density in each field was measured by counting the number of soybean plant in a $\mathrm{m}^{2}$ area using it to calculate plant population per hectare.

\subsection{Statistical Analysis}

Analysis of variance was performed using the Statistical Analysis Software (SAS) Version 9.4 (Johannesburg, South Africa). Effects were considered significant in all statistical calculation if the $p$-values were $\leq 0.05$. The mean separation was done using Duncan's test.

\section{Results}

\subsection{Growth and Yield Parameters of Soybean Crop}

\subsubsection{Plant Emergence}

In both climatic zones (A and B), plant emergence of the soybean crop was significantly $(p<0.05)$ different under liquid formulation of B. japonicum inoculant WB74 and in the reference registered standard used in comparison to the control treatment (Figure 1A). Similarly, plant emergence in the peat formulation dosage of B. japonicum inoculant WB74 and reference registered standard used was significantly $(p<0.05)$ different compared to the control (Figure 1B). No significant $(p>0.05)$ differences were observed between the two bioclimatic zones (A and $\mathrm{B})$.

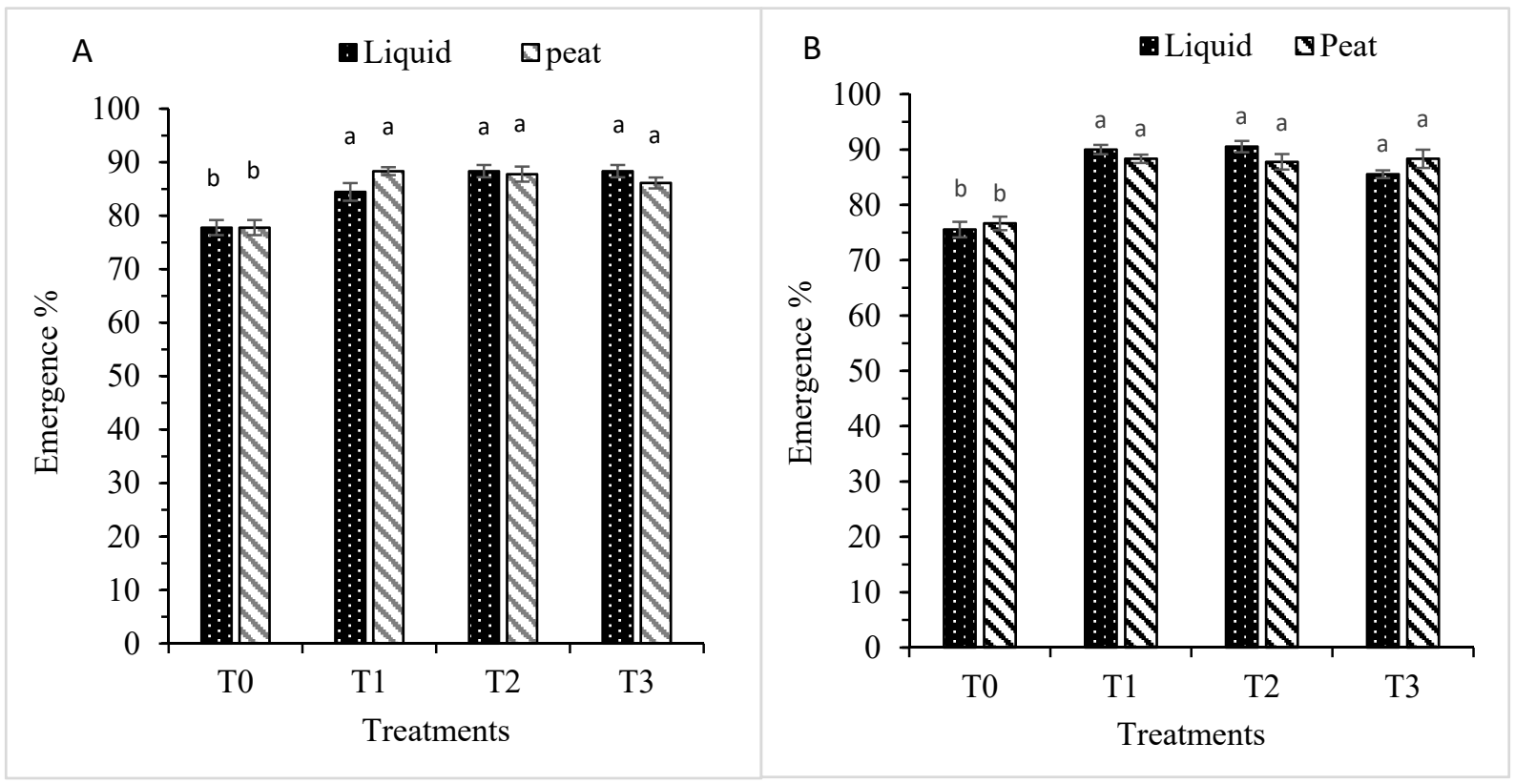

Figure 1. Plant emerging rate of soybean plants subjected to liquid formulation $(\mathrm{T} 0=0 \mathrm{~mL}, \mathrm{~T} 1=150 \mathrm{~mL}, \mathrm{~T} 2=300 \mathrm{~mL}$ and $\mathrm{T} 3=150 \mathrm{~mL})$ and peat formulation of Bradyrhizobium japonicum $(\mathrm{T} 0=0 \mathrm{~g}, \mathrm{~T} 1=250 \mathrm{~g}, \mathrm{~T} 2=500 \mathrm{~g}$ and $\mathrm{T} 3=150 \mathrm{~mL}) \mathrm{in}$ bioclimatic zone $((\mathbf{A})=$ Bronkhorspruit/Gauteng $)$ and $(\mathbf{B})=$ Hartbeesfoein/North West province). Bars sharing a letter are not significantly different $($ Lsd zone $A)=5.139$ and $($ Lsd zone $B)=5.442$. Data are means \pm standard errors. 


\subsubsection{Plant Height}

In bioclimatic zone $\mathrm{A}$, plant height of the soybean crop was significantly $(p<0.05)$ different under liquid formulation of B. japonicum inoculant WB74 and reference registered standard used compare to the control. Similarly, plant height of peat formulation of $B$. japonicum inoculant WB74 and reference registered standard used was significantly $(p<0.05)$ different compared to the control (Figure 2A). In bioclimatic zone B, plant height of the soybean crop was significantly $(p<0.05)$ different compare to the control under liquid formulation of B. japonicum inoculant WB74 and reference registered standard used. Similarly, plant height of peat formulation of B. japonicum inoculant WB74 and reference registered standard used was significantly $(p<0.05)$ different compare to the control (Figure 2B).
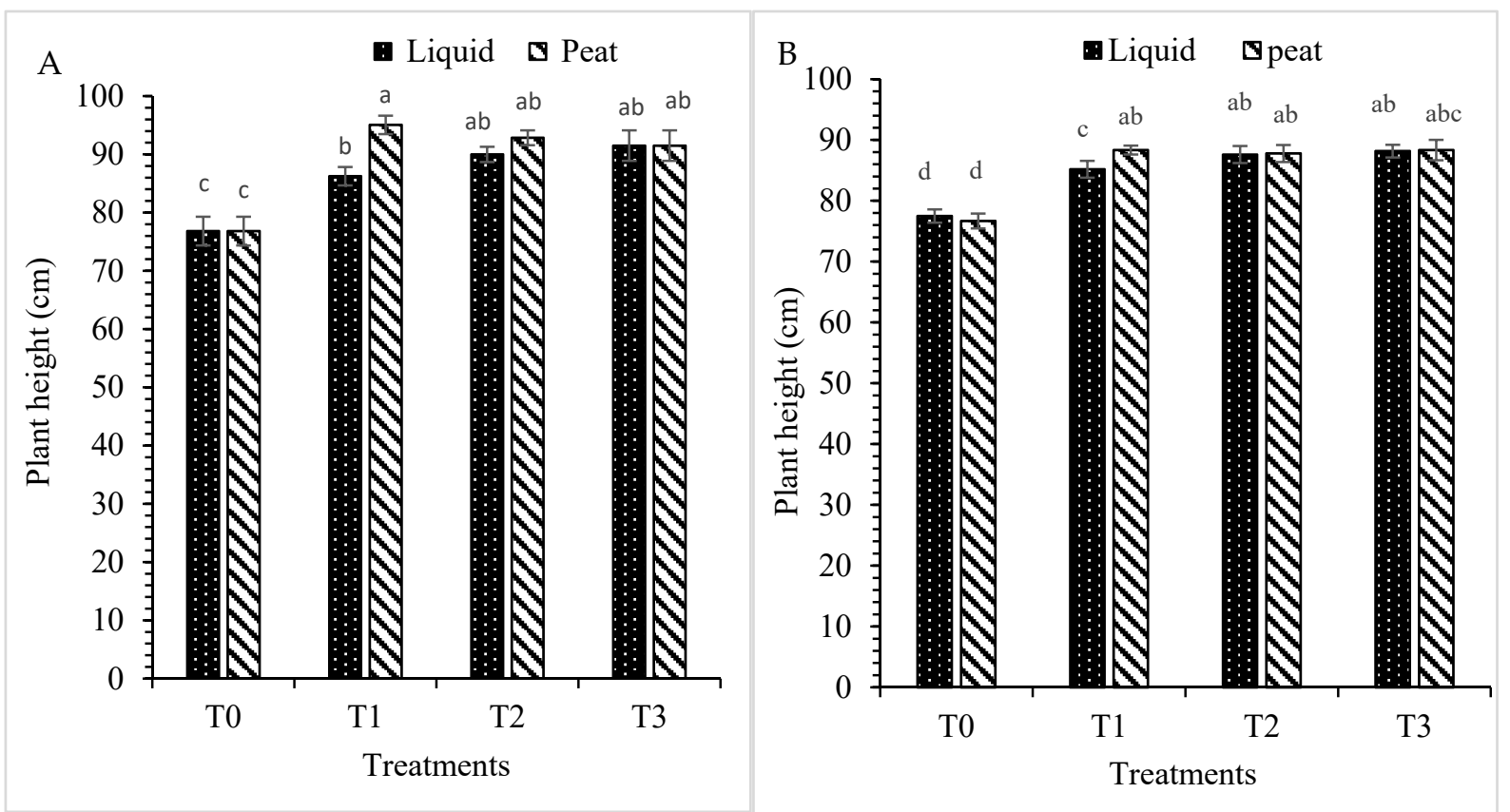

Figure 2. Plant height of soybean plants subjected to liquid formulation (T0 $=0 \mathrm{~mL}, \mathrm{~T} 1=150 \mathrm{~mL}, \mathrm{~T} 2=300 \mathrm{~mL}$ and $\mathrm{T} 3=150$ $\mathrm{mL}$ ) and peat formulation of Bradyrhizobium japonicum ( $\mathrm{T} 0=0 \mathrm{~g}, \mathrm{~T} 1=250 \mathrm{~g}, \mathrm{~T} 2=500 \mathrm{~g}$ and $150 \mathrm{~mL})$ in bioclimatic zone $((\mathbf{A})=$ Bronkhorspruit/Gauteng $)$ and $((\mathbf{B})=$ Hartbeesfoein/North West province). Bars sharing a letter are not significantly different $($ Lsd zone $A)=8.749$ and $($ Lsd zone $B)=5.124$. Data are means \pm standard errors.

\subsubsection{Root Length}

In bioclimatic zone $A$, root length of the soybean crop was significantly different under liquid formulation of B. japonicum inoculant WB74 (T1) compared to the control. Meanwhile WB74 (T2) and reference registered standard (T3) used were not significantly $(p>0.05)$ different compared to the control (Figure 3A). Root length of formulation dosage of $B$. japonicum, soybean crop was significantly $(p<0.05)$ different under formulation of B. japonicum inoculant WB74 (T2) compared to the control. Meanwhile WB74 (T1) and reference registered standard (T3) used were not significantly $(p>0.05)$ different compared to the control. In bioclimatic zone B, root length of the soybean crop was significantly $(p<0.05)$ different under liquid formulation of B. japonicum inoculant WB74 and reference registered standard used compared to the control (Figure 3B). Similarly, root length of peat formulation dosage of B. japonicum inoculant WB74 and reference registered standard used was significantly $(p<0.05)$ different compared to the control. 


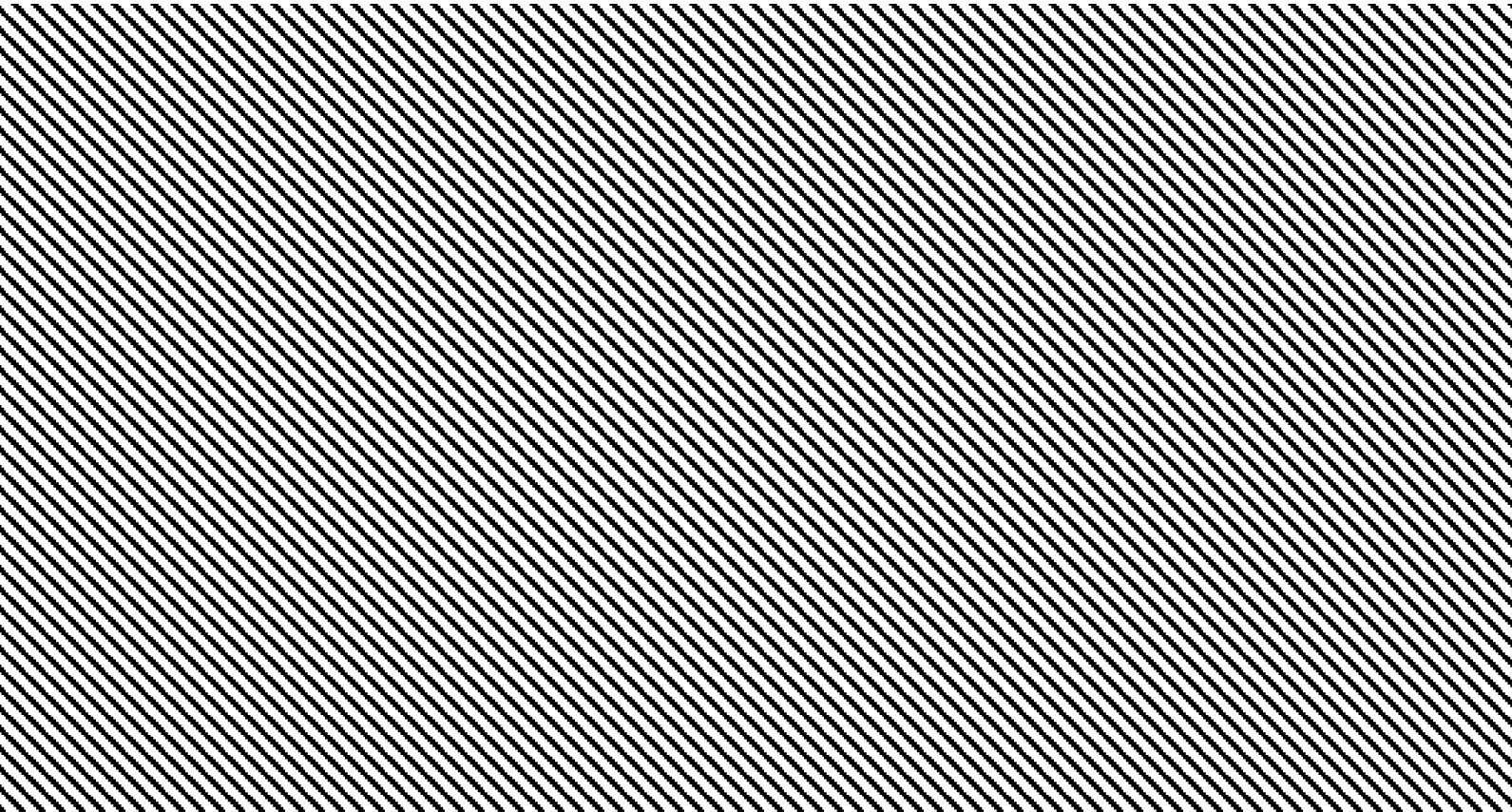

Figure 3. Root length subjected to liquid formulation ( $\mathrm{T} 0=0 \mathrm{~mL}, \mathrm{~T} 1=150 \mathrm{~mL}, \mathrm{~T} 2=300 \mathrm{~mL}$ and $\mathrm{T} 3=150 \mathrm{~mL}$ ) and peat formulation of Bradyrhizobium japonicum (T0 = $0 \mathrm{~g}, \mathrm{~T} 1=250 \mathrm{~g}, \mathrm{~T} 2=500 \mathrm{~g}$ and $150 \mathrm{~mL}$ ) in bioclimatic zone $((\mathbf{A})=$ Bronkhorspruit/Gauteng $)$ and $((\mathbf{B})=$ Hartbeesfoein/North West province). Bars sharing a letter are not significantly different $($ Lsd zone $A)=8.063$ and $($ Lsd zone $B)=2.541$. Data are means \pm standard errors.

\subsubsection{Number of Nodules}

There was a significant $(p<0.05)$ difference in the number of nodules of the soybean crop in bioclimatic zone A under liquid formulation of B. japonicum WB74 and reference registered standard used compared to the control (Figure 4 A). Similarly, number of nodules of peat formulation of B. japonicum WB74 and reference registered standard used was significantly different compared to the control. In bioclimatic zone $B$, number of nodules of the soybean crop was significantly different compared to the control under liquid formulation of B. japonicum WB74 and reference registered standard used (Figure 4B). Similarly, number of nodules of peat formulation of B. japonicum WB74 and reference registered standard used was significantly different compare to the control.

\subsubsection{Size of Nodules}

In bioclimatic zone $\mathrm{A}$, size of nodules of the soybean crop was significantly different under liquid formulation of B. japonicum inoculant WB74 and reference registered standard used compared to the control (Figure 5A). Similarly, size of nodules of peat formulation dosage of $B$. japonicum inoculant WB74 and reference registered standard used was significantly different with reference to the control. In bioclimatic zone B, size of nodules of the soybean crop was significantly different compared to the control under liquid formulation of B. japonicum inoculant WB74 and reference registered standard used (Figure 5B). Similarly, size of nodules of peat formulation of B. japonicum WB74 and reference registered standard used was significantly different in comparison to the control. Additionally, in bioclimatic B size of nodules in liquid formulation was significantly higher compared to peat formulation B. japonicum WB74 and reference registered standard treatments. 


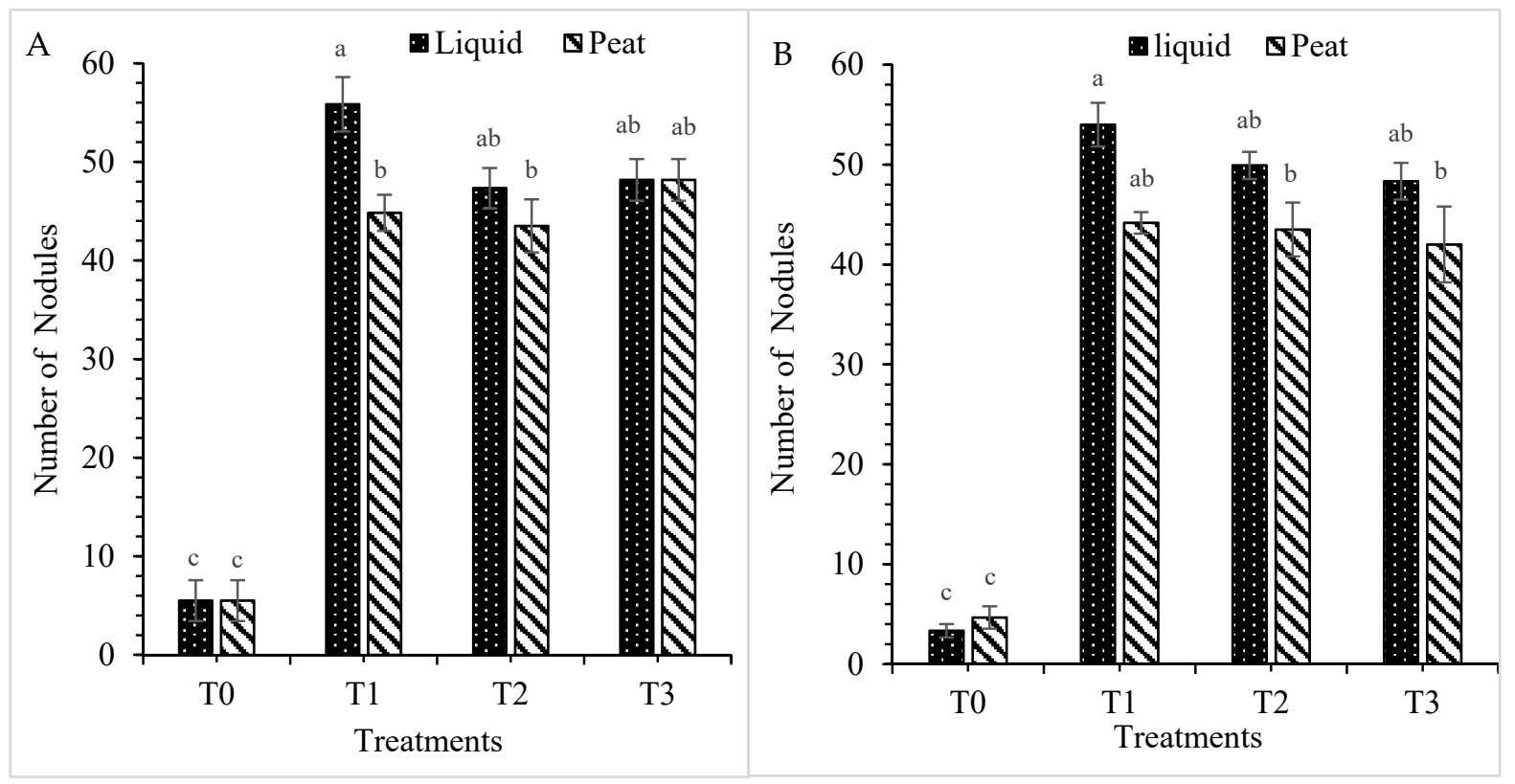

Figure 4. Number of nodules of soybean plants subjected to liquid formulation $(\mathrm{T} 0=0 \mathrm{~mL}, \mathrm{~T} 1=150 \mathrm{~mL}, \mathrm{~T} 2=300 \mathrm{~mL}$ and $\mathrm{T} 3$ $=150 \mathrm{~mL}$ ) and peat formulation of Bradyrhizobium japonicum $(\mathrm{T} 0=0 \mathrm{~g}, \mathrm{~T} 1=250 \mathrm{~g}, \mathrm{~T} 2=500 \mathrm{~g}$ and $150 \mathrm{~mL})$ in bioclimatic zone $((\mathbf{A})=$ Bronkhorspruit/Gauteng $)$ and $((\mathbf{B})=$ Hartbeesfoein/North West province). Bars sharing a letter are not significantly different $($ Lsd zone $A)=10.167$ and $($ Lsd zone $B)=9.978$. Data are means \pm standard errors.

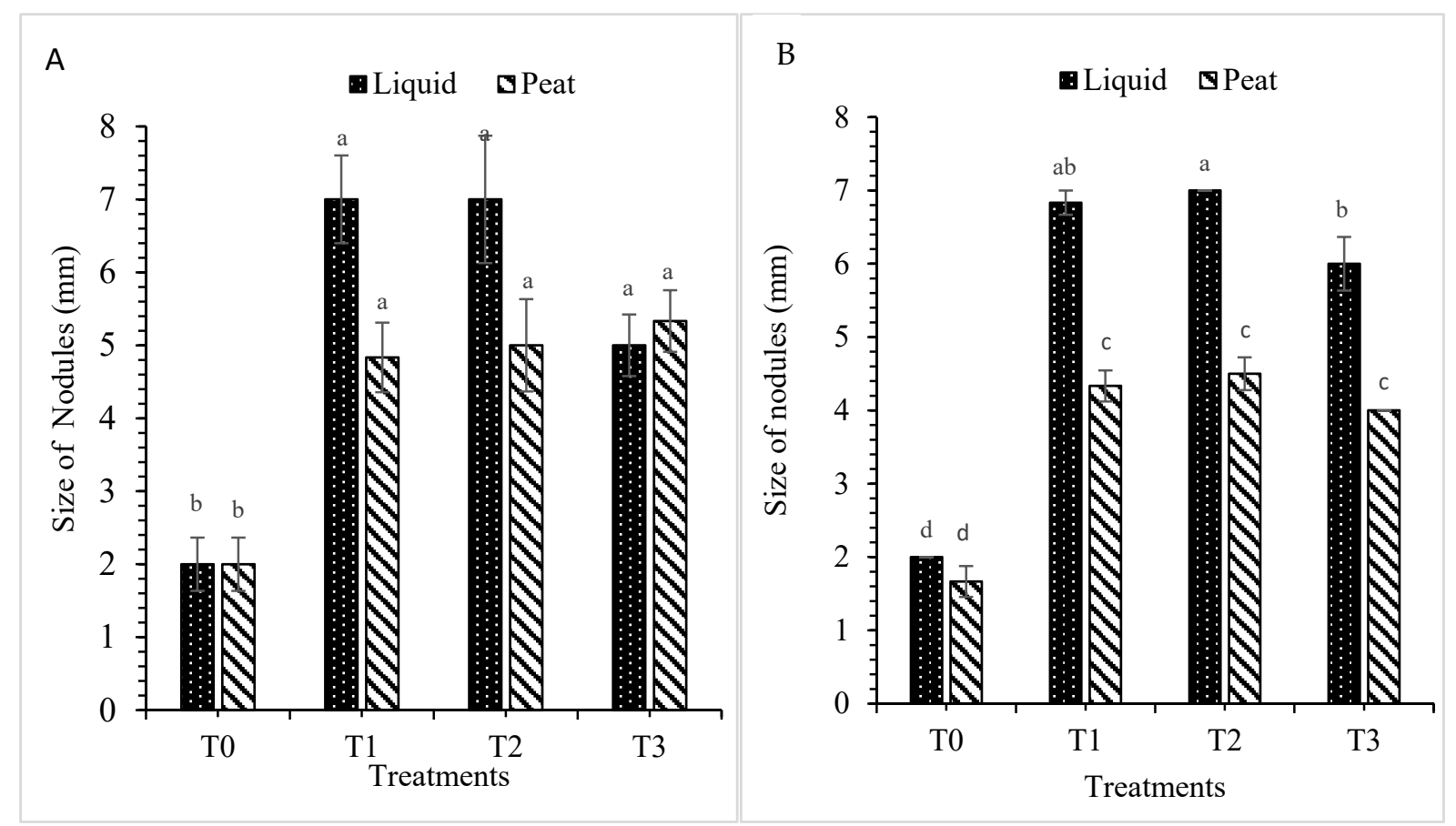

Figure 5. Size of nodules of soybean plants subjected to liquid formulation $(\mathrm{T} 0=0 \mathrm{~mL}, \mathrm{~T} 1=150 \mathrm{~mL}, \mathrm{~T} 2=300 \mathrm{~mL}$ and $\mathrm{T} 3=$ $150 \mathrm{~mL}$ ) and peat formulation of Bradyrhizobium japonicum $(\mathrm{T} 0=0 \mathrm{~g}, \mathrm{~T} 1=250 \mathrm{~g}, \mathrm{~T} 2=500 \mathrm{~g}$ and $150 \mathrm{~mL})$ in bioclimatic zone $((\mathbf{A})=$ Bronkhorspruit/Gauteng $)$ and $((\mathbf{B})=$ Hartbeesfoein/North West province). Bars sharing a letter are not significantly different $($ Lsd zone $A)=2.511$ and $($ Lsd zone $B)=0.934$. Data are means \pm standard errors

\subsubsection{Yield}

In bioclimatic zone A, yield of the soybean crop was significantly $(p>0.05)$ different under liquid formulation of B. japonicum inoculant WB74 and reference registered standard 
used compare to the control (Figure 6A). Similarly, yield of peat formulation of B. japonicum inoculant WB74 and reference registered standard used was significantly different compare to the control. In bioclimatic zone B, yield of the soybean crop was significantly different under liquid formulation of $B$. japonicum inoculant WB74 and reference registered standard used compare to the control (Figure 6B). Similarly, yield of peat formulation of B. japonicum inoculant WB74 and reference registered standard used was significantly different compared to the control. In bioclimatic zone B, the formulation liquid produced significantly higher yield than peat formulation in B. japonicum inoculant WB74 and reference registered standard.

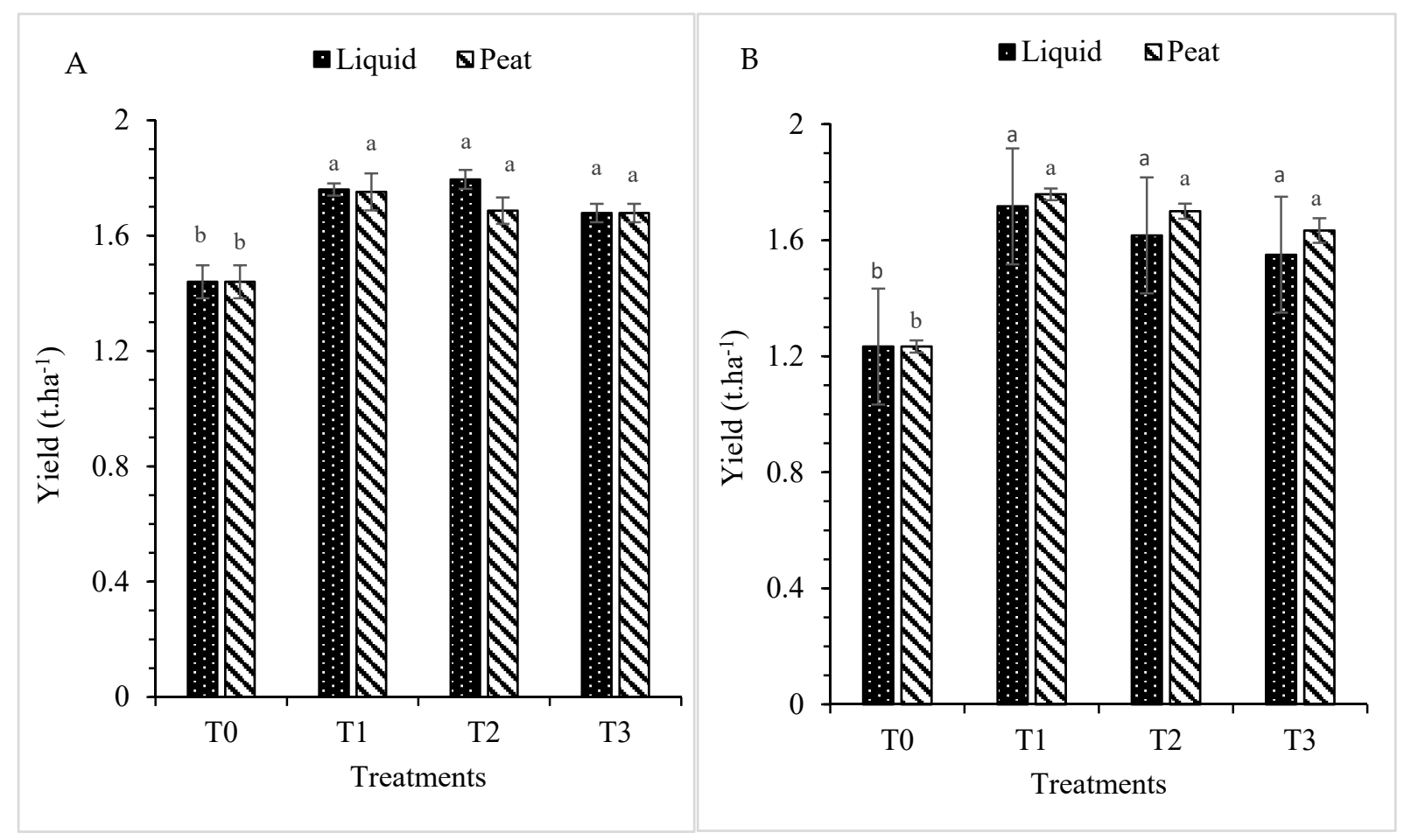

Figure 6. Yield of soybean plants subjected to liquid formulation $(\mathrm{T} 0=0 \mathrm{~mL}, \mathrm{~T} 1=150 \mathrm{~mL}, \mathrm{~T} 2=300 \mathrm{~mL}$ and $\mathrm{T} 3=150 \mathrm{~mL})$ and peat formulation of Bradyrhizobium japonicum $(\mathrm{T} 0=0 \mathrm{~g}, \mathrm{~T} 1=250 \mathrm{~g}, \mathrm{~T} 2=500 \mathrm{~g}$ and $150 \mathrm{~mL})$ in bioclimatic zone $((\mathbf{A})$ $=$ Bronkhorspruit/Gauteng) and $((\mathbf{B})=$ Hartbeesfoein/North West province). Bars sharing a letter are not significantly different $($ Lsd zone $A)=0.209$ and $($ Lsd zone $B)=0.108$. Data are means \pm standard errors.

\subsubsection{Nitrogen Concentration with Dumas Analysis}

Soybean nitrogen concentration was improved in B. japonicum inoculant WB74 (T1 and T2) compared to the control for liquid and peat inoculant (Figure 7). Meanwhile, no difference was observed between the reference registered standard used with liquid and peat inoculant and the control. However, treatment T2 increased soybean nitrogen concentration compared to T1 and T3 in both liquid and peat inoculant. The data shows that application of B. japonicum inoculant WB74 (T1and T2) increased soybean nitrogen concentration compared to the control treatment (T0) in both bioclimatic zones. Meanwhile, the standard registered improved slightly soybean nitrogen concentration compared to the control in bioclimatic zone A.

\subsubsection{Nitrogen Fixed}

For the $\delta^{15} \mathrm{~N}$ of soybean plant samples were calculated using (Equation (2)), then the value for each treated was used to calculated $\mathrm{N}$-fixed. The nitrogen derived from the atmosphere was higher for B. japonicum WB74 (T1 and T2) compare to the T3 (registered standard) and control treatment. The increased of ${ }^{15} \mathrm{~N}$ isotope with B. japonicum WB74 (T1 and T2) were shown in both liquid and peat inoculant (Figure 8). However, liquid 
inoculant showed higher nitrogen fixation per hectare compared to peat inoculant with WB74 for (T1 and T2) treatments. $\mathrm{N}$ fixation measure by isotopic method $\left({ }^{15} \mathrm{~N}\right.$ isotope) nitrogen fixation was increased with $\mathrm{T} 1$ and $\mathrm{T} 2$ in both bioclimatic zones in both peat and liquid inoculate formulation. For liquid inoculant, kilogram per hectare were, respectively, $\mathrm{T} 0=200 ; \mathrm{T} 1=250 ; \mathrm{T} 2=310$ and $\mathrm{T} 3=150$, while for the peat, $\mathrm{T} 0=100 ; \mathrm{T} 1=220 ; \mathrm{T} 2=228$ and $\mathrm{T} 3=164$.

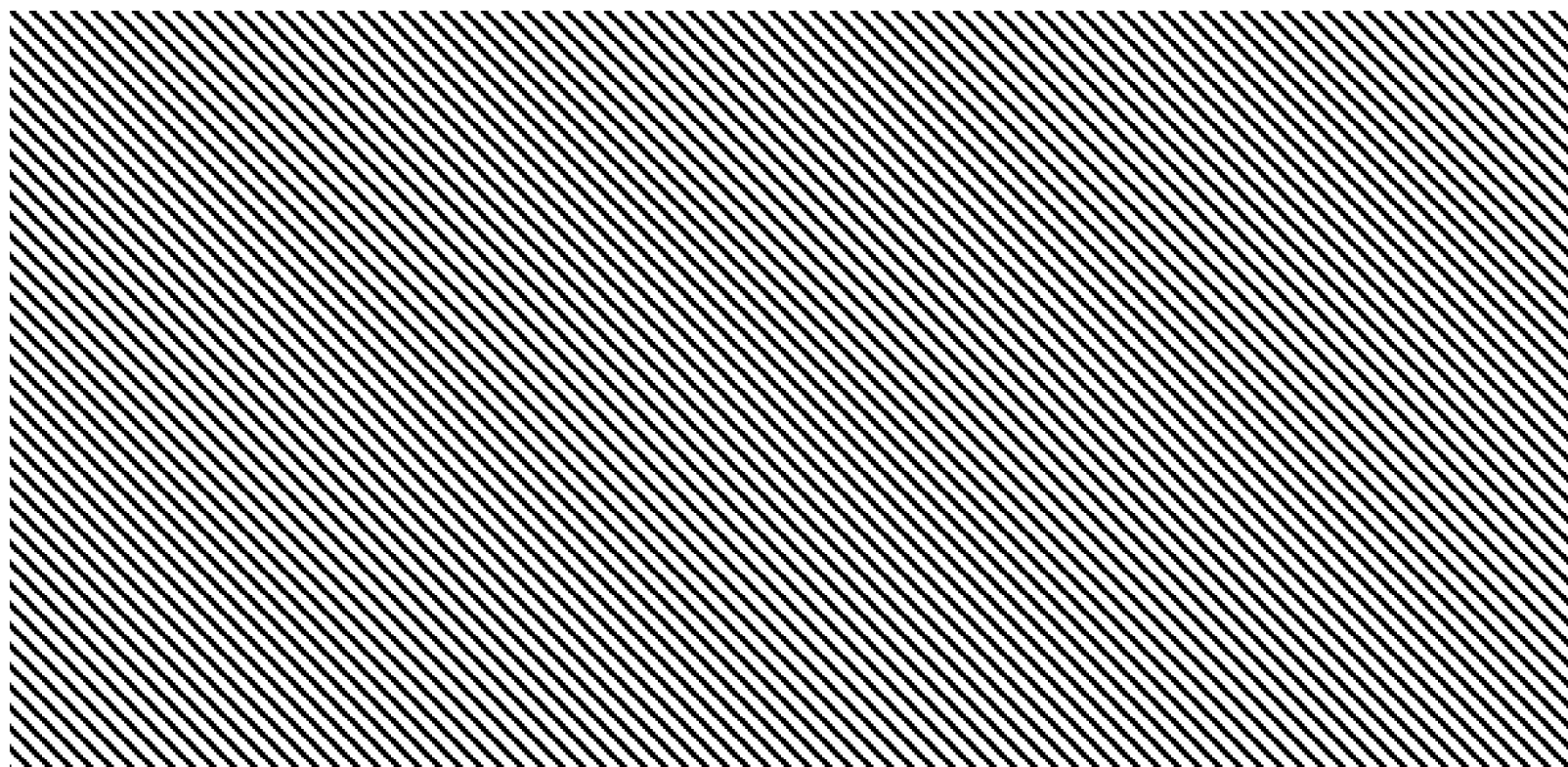

Figure 7. Nitrogen concentrate in soybean plants subjected to liquid formulation (T0 = $0 \mathrm{~mL}, \mathrm{~T} 1=150 \mathrm{~mL}, \mathrm{~T} 2=300 \mathrm{~mL}$ and $\mathrm{T} 3=150 \mathrm{~mL})$ and peat formulation of Bradyrhizobium japonicum $(\mathrm{T} 0=0 \mathrm{~g}, \mathrm{~T} 1=250 \mathrm{~g}, \mathrm{~T} 2=500 \mathrm{~g}$ and $150 \mathrm{~mL})$ in bioclimatic zone $((\mathbf{A})=$ Bronkhorspruit $/$ Gauteng $)$ and $((\mathbf{B})=$ Hartbeesfoein $/$ North West province $)$. Data are means \pm standard errors.

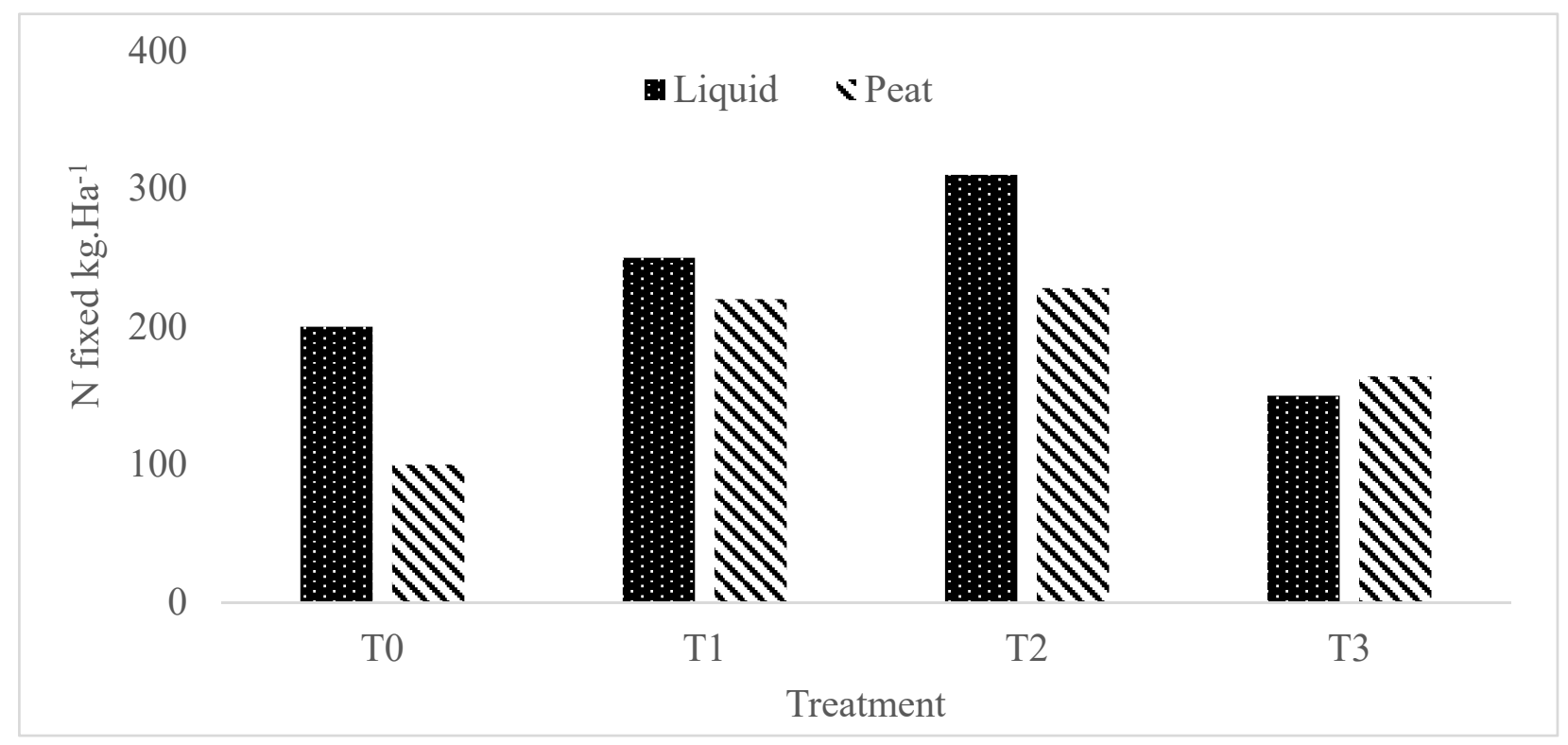

Figure 8. Nitrogen fixed $\mathrm{kg} \mathrm{ha}^{-1}$ of soybean plants subjected to liquid and peat of Bradyrhizobium japonicum inoculum $\mathrm{T} 0=$ untreated control, $\mathrm{T} 1=150 \mathrm{~mL}, \mathrm{~T} 2=300$ and T3 $=150 \mathrm{~mL}$ for liquid inoculant and $\mathrm{T} 0=$ untreated control, $\mathrm{T} 1=250 \mathrm{~g}$, $\mathrm{T} 2=500 \mathrm{~g}$ and $\mathrm{T} 3=150 \mathrm{~mL}$ (standard registered) for the peat inoculant. 


\section{Discussion}

Results of both bio-climatic zones with Bradyrhizobium japonicum strain WB74 revealed that inoculant had a positive effect on growth, yield and nitrogen fixation. With respect to plant height, treatment with inoculation (T1 and T2) and reference standard (T3) were significantly higher compared to un-inoculated treatment in both climate zones and formulations (peat and liquid) Figure 2. The study by Argaw (2012) [24], reported that plant height was increased with product inoculated compared to the control and other treatments. Research experiments have shown that inoculation with rhizobium has higher positive responses on soybean growth compare to the untreated control and this is justified, at least in soil that has never grown legume before or has not grown this for many years [25]. Results on the study that was done on the major nod factor of B. japonicum promotes early growth of soybean and corn [26]. In another study which was done on yields and economic benefits of soybean (Glycine max L.) as affected by B. japonicum inoculation and phosphorus supplementation, results highlighted that growth of soybean with the inoculated treatment was significantly higher than non-inoculated treatment [27].

A study conducted by Zerpa et al. 2013 [28], on the effects of B. japonicum inoculants on soybean (Glycine max (L.) Merr.) nodulation and growth improvement showed that plant height was significantly increased when compared to the control treatment that was not inoculated. The increase in soybean height was attributed to specificity existing between rhizobial strain and the legume, and compatibility between the two, as that is essential for successful nodulation that will impact on nitrogen fixation and enhance crop growth [29]. In another study, the effect of Rhizobium inoculants and reproductive growth stages was evaluated for its impact on shoot biomass and yield of soybean, which revealed that Bradyrhizobium inoculant increased soybean height compared to the control treatment [30]. Crop establishment correlates with plant emergence rate, inoculated plants were highly established compared to the non-inoculated soybean seed and this suggests that plant vigor was enhanced due to the improved soil health. Soil health improvement increased plant emergence rate in rhizobia treated plants. It was demonstrated that plant growth promotor bacteria enhance plant nutrient uptake capability and exert plant growth promoting effects via the stimulation of soil condition [13]. Soybean yield in B. japonicum treatments (T1 and T2) and reference standard (T3) were significantly higher compared to the control in both climate zones and both types of formulations (Figure 6). Our results rendered similar results with several other studies that soybean application with formulated products of $B$. japonicum resulted in significant increase in seed yield and total $\mathrm{N}$ as compared to control treatments [24,31-33].

In the current study, size of nodules, number of nodules and yield were significantly higher compared to the non-inoculated treatment (Figures 4-6). This corroborates with a study conducted by Souleimanov et al. 2002 [26], on the effects of inoculation by $B$. japonicum strains on nodulation, nitrogen fixation, and yield of soybean (Glycine max L. Merill) varieties on Nitisols of Bako, in Western Ethiopia. In their findings they reported that $B$. japonicum significantly increased soybean seed yield and yield components such as number of pods per plant, number of seeds per pod, seed yield, thousand seed weight and above-ground dry biomass. In an experiment conducted by Argaw (2012) [24], it was reported that the number of nodules were increased in plants inoculated with $B$. japonicum compared to the uninoculated treatment. Similarly, the study conducted on growth and yield of soybean varieties inoculated with Bradyrhizobium spp. strains in N-deficient calcareous soils revealed that significant positive effects on growth, nodule number and yield of soybeans were obtained after inoculation with Bradyrhizobium spp. strains $[34,35]$. A similar study showed that $B$. japonicum increased soybean yield significantly with the inoculated treatment compared to the uninoculated [27].

Findings from our research regarding nitrogen uptake (Figure 7) concurs with results that were reported in a study that investigated the effect inoculation by B. japonicum strains on nodulation, nitrogen fixation, and yield of soybean varieties on Nitisols of Bako, 
Western Ethiopia. These results demonstrated that nitrogen uptake was significantly higher at flowering stage, which was attributed to the effect of rhizobial strain [14].

Nitrogen fixation with ${ }^{15}$ Nisotope was improved in inoculated soybean compared to un-inoculated plants in both liquid and peat formulations (Figure 8). The nitrogen fixation increases correlate to nodule formation. This implies that nodules size and number increments influence the nitrogen fixation rate. Similarly, Htwe et al., 2019 [35], demonstrated that a significant increment in plant growth and nodulation influences nitrogen fixation improvement in mung beans and soybeans. In addition, soybean inoculated with B. japonicum demonstrated a significant increase in nitrogen fixation and nitrogen uptake in inoculated treatments compared to un-inoculated one, which concurs with the current results [11].

It seemed apparent from the responses obtained in the current investigation that the moderately acidic soil $\mathrm{pH}$ in bioclimatic zone A did not affect the bacterial strains, the soybean plant growth, nodulation and yield, and the crop and bacteria symbiotic relationship. This agrees with the study conducted in soybean under moderately acidic soil, whereby there was no impact on soybean plant due to acidic soil and its relationship with the bacteria strain [14].

Nodulation formation was highly impacted by the peat inoculant in bioclimatic zone B (Figure 5). Ref. [36] also demonstrated a positive increment in nodulation and yield of soybean subjected to bio-fertilizers and organic manures treatments compared to the control. Ref. [37] also reported similar results in the study conducted on the assessment of the efficiency of different formulations of $B$. japonicum and effect of co-inoculation of Bacillus subtilis with two different strains of $B$. japonicum. Their results revealed that $B$. japonicum increased nodules in soybean.

Regarding size of nodules, the liquid inoculant demonstrated a significantly high nodule size compared to peat inoculant in zone B. This could suggest that liquid culture is most suitable form to achieve optimum impact on crop yield, growth and nodulation under sandy loam soil.

\section{Conclusions}

The results of the present study have indicated that it is important to promote the appropriate use of bio-fertilizer such as microorganism. The study proves that both liquid and peat $B$. japonicum inoculants increased soybean growth and yield. Nitrogen uptake was higher with $\mathrm{T} 2$ and $\mathrm{T} 3$ in both liquid and peat formulations, and bioclimatic zones. The increase in nodule formation in $B$. japonicum inoculated plants led to the increase in nitrogen fixation which results in the improvement in soil health. This study also provides substantiate evidence that $B$. japonicum inoculant used was compatible with the soybean cultivar LINK 6150. Therefore, significant increments in plant growth, number of nodules, size of nodules, nitrogen uptake, nitrogen fixation and yield were found in soybeans. Growth parameters, yield and nodulation formation were not impacted under the acidic soil in bioclimatic zone B. Both liquid and peat formulations are recommended for $B$. japonicum inoculant with proper consideration given depending on the soil type. Therefore, more efforts need to be done to compare peat and liquid B. japonicum strain WB74 inoculant on soybean crop. Nitrogen fixation was improved in inoculated soybean compared to un-inoculated plants in both liquid and peat formulations. The nitrogen fixation positive correlation to nodule formation demonstrated that nodules size and number increments influenced the nitrogen fixation rate. Moreover, the increase in nitrogen fixation in in B. japonicum inoculated plants will promote adaptation to abiotic stress conditions which could be investigated in further research.

Author Contributions: A.G., contributed to fieldwork, methodology and manuscript writing and discussion A.I.H., M.A.M.-S., E.M. for formal analysis, methodology and manuscript writing and discussion. B.J.V., R.M., contributed to writing and discussion of the final manuscript. All authors have read and agreed to the published version of the manuscript. 
Funding: We are grateful to the University of Pretoria for supporting this study.

Data Availability Statement: Not applicable.

Conflicts of Interest: The authors declare no conflict of interest.

\section{References}

1. Rodriĝues-Navarro, D.N.; Oliver, I.M.; Contreras, M.A.; Ruiz-Sainz, J.E. Soybean interactions with soil microbes, agronomical and molecular aspects. Agron. Sustain. Dev. 2011, 31, 173-190. [CrossRef]

2. FAO (Food and Agriculture Organization of the United Nations). FAOSTAT; Food and Agriculture Organization of the United Nations: Rome, Italy, 2011.

3. United States Department of Agriculture (USDA). World Soybean Production 2020/2021. Available online: WorldAgricultural. com (accessed on 23 July 2021).

4. FAOSTAT. FAO Statistics; Food and Agriculture Organization of the United Nations: Rome, Italy, 2012. Available online: http:/ / faostat3.fao.org/browse/Q/QC/E (accessed on 11 May 2015).

5. South African Bureau for Food and Agricultural Policy. 2013.

6. Department of Trade and Industry. Industrial Policy Action Plan 2012/13-2014/15; Department of Trade and Industry: Pretoria, South Africa, 2010.

7. De Beer, A.; Prinsloo, T. The National Soybean Cultivar Trials in South Africa-34 Years' Experiences and Progress; Agric Cultural Research Council, Grain Crops Institute: Potchefstroom, South Africa, 2013.

8. Sahoo, R.K.; Bhardwaj, D.; Tuteja, N. Bio-fertilizers: A sustainable eco-friendly agricultural approach to crop improvement. In Plant Acclimation to Environmental Stress; Springer: New York, NY, USA, 2013; pp. 403-432.

9. Ruzzi, M.; Aroca, R. Plant growth-promoting rhizobacteria act as bio-stimulants in horticulture. Sci. Hortic. 2015, 196, 124-134. [CrossRef]

10. Abaidoo, R.C.; Keyser, H.H.; Singleton, P.W.; Dashiell, K.E.; Sanginga, N. Population size, distribution, and symbiotic characteristics of indigenous Bradyrhizobium spp. that nodulate TGx soybean genotypes in Africa. Appl. Soil Ecol. 2007, $35,57-67$. [CrossRef]

11. Hussain, K.; Islam, M.; Siddique, M.T.; Hayat, R.; Molisan, S.O. Soybean Growth and Nitrogen Fixation as Affected by Sulfur Fertilization and Inoculation Under rainfed conditions in Pakistan. Int. J. Agric. Biol. 2011, 13, 951-955.

12. Weisany, W.; Raei, Y.; Allahverdipoor, K.H. Role of some of mineral nutrients in biological nitrogen fixation. Bull. Environ. Pharmacol. Life Sci. 2013, 2, 77-84.

13. Bai, Y.; Zhou, X.; Smith, D.L. Enhanced soybean plant growth resulting from co-inoculation of Bacillus strains with Bradyrhizobium japonicum. Crop Sci. 2003, 43, 1774-1781. [CrossRef]

14. Solomon, T.; Pant, L.M.; Angaw, T. Co (Glycine max L. Merill) varieties on nitisols of Bako, Western Ethiopia. ISRN Agron. 2012. [CrossRef]

15. Bhangoo, M.S.; Albritton, D.J. Nodulating and nonnodulating Soybean isolines response applied nitrogen. Agron. J. 1996, 68, 642-645. [CrossRef]

16. Mburu, M.W.; Okalebo, J.R.; Lesueur, D.; Pypers, P.; Ng'etich, W.; Mutegi, E.; Nekesa, O.A. Evaluation of biological commercial inoculants on soybean production in Bungoma county, Kenya. In Proceedings of the 10th African Crop Science Conference Proceedings, Maputo, Mozambique, 10-13 October 2011; pp. 605-610.

17. Bulgari, R.; Cocetta, G.; Trivellini, A.; Vernieri, P.; Ferrante, A. Bio-stimulants and crop responses: A review. Biol. Agric. Hortic. 2015, 31, 1-17. [CrossRef]

18. Halpern, M.; Bar-Tal, A.; Ofek, M.; Minz, D.; Muller, T.; Yermiyahu, U. The use of biostimulants for enhancing nutrient uptake. Adv. Agron. 2015, 130, 141-174.

19. Kuypers, M.M.; Marchant, H.K.; Kartal, B. The microbial nitrogen-cycling network. Nat. Rev. Microbiol. 2018, 16, 263. [CrossRef] [PubMed]

20. Biradar, B.P.; Santhosh, G.P. Role of Polymeric Additives in Formulation, Shelf-life and Bioefficacy of Liquid Inoculant of Pseudomonas fluorescens. Int. J. Pure App. Biosci. 2018, 6, 123-133. [CrossRef]

21. Kottek, M.; Grieser, J.; Beck, C.; Rudolf, B.; Rubel, F. World Map of the Koppen-Gieger Climate Classification Updated. Meteorol. Z. 2006, 15, 259-263. [CrossRef]

22. Soil Classification Working Group. 1991; South Africa.

23. Jackson, M.C. Soil Chemical Analysis; Prentice Hall: Englewood Cliffs, NJ, USA, 1975.

24. Argaw, A. Evaluation of co-inoculation of Bradyrhizobium japonicum and Phosphate solubilizing Pseudomonas spp. effect on soybean (Glycine max L. Merr.) in Assossa Area. J. Agric. Sci. Technol. 2012, 14, 213-224.

25. Thao, T.Y. Need for and benefits of soybean inoculation of the south Vietnam. In Proceedings of the National Conference of Soybean, VASI-CSIRO (Vietnam-Australia), Hanoi, Vietnam, 22-23 March 2001.

26. Souleimanov, A.; Prithiviraj, B.; Smith, D.L. The major Nod factor of Bradyrhizobium japonicum promotes early growth of soybean and corn. J. Exp. Bot. 2002, 53, 1929-1934. [CrossRef] [PubMed]

27. Tairo, E.V.; Ndakidemi, P.A. Yields and economic benefits of soybean (Glycine max L.) as affected by Bradyrhizobium japonicum inoculation and phosphorus supplementation. Am. J. Res. Commun. 2013, 1, 159-172. 
28. Zerpa, M.; Mayz, J.; Méndez, J. Effects of Bradyrhizobium japonicum inoculants on soybean (Glycine max (L.) Merr.) growth and nodulation. Ann. Biol. Res. 2013, 4, 193-199.

29. Dwivedi, S.L.; Sahrawat, K.L.; Upadhyaya, H.D.; Mengoni, A.; Galardini, M.; Bazzicalupo, M.; Biondi, E.G.; Hungria, M.; Kaschuk, G.; Blair, M.W.; et al. Advances in host plant and rhizobium genomics to enhance symbiotic nitrogen fixation in grain legumes. Adv. Agron. 2015, 129, 1-116.

30. Lamptey, S.; Ahiabor BD, K.; Yeboah, S.; Osei, D. Effect of rhizobium inoculants and reproductive growth stages on shoot biomass and yield of soybean (Glycine max (L.) merril). J. Agric. Sci. 2014, 6, 44. [CrossRef]

31. Kumaga, F.K.; Ofori, K. Response of soybean (Glycine max (L.) Merrill) to Bradyrhizobia inoculation and phosphorus application. Int. J. Agric. Biol. 2004, 6, 324-327.

32. De Bruin, J.L.; Pedersen, P.; Conley, S.P.; Gaska, J.M.; Naeve, S.L.; Kurle, J.E.; Elmore, R.W.; Giesler, L.J.; Abendroth, L.J. Probability of yield response to inoculants in fields with a history of soybean. Crop Sci. 2010, 50, 265-272. [CrossRef]

33. Vitosh, M.L. Soybean Inoculation in Michigan; Department of Crop and Soil Sciences, Michigan State University: Ann Arbor, MI, USA, 1997.

34. Egamberdiyeva, D.; Qarshieva, D.; Davranov, K. Growth and yield of soybean varieties inoculated with Bradyrhizobium spp in N-deficient calcareous soils. Biol. Fertil. Soils 2004, 40, 144-146. [CrossRef]

35. Htwe, A.Z.; Moh, S.M.; Soe, K.M.; Moe, K.; Yamakawa, T. Effects of biofertilizer produced from Bradyrhizobium and Streptomyces griseoflavus on plant growth, nodulation, nitrogen fixation, nutrient uptake, and seed yield of mung bean, cowpea, and soybean. Agronomy 2019, 9, 77. [CrossRef]

36. Javaid, A.; Mahmood, N. Growth, nodulation and yield response of soybean to biofertilizers and organic manures. Pak. J. Bot. 2010, 42, 863-871.

37. Atieno, M.; Herrmann, L.; Okalebo, R.; Lesueur, D. Efficiency of different formulations of Bradyrhizobium japonicum and effect of co-inoculation of Bacillus subtilis with two different strains of Bradyrhizobium japonicum. World J. Microbiol. Biotechnol. 2012, 28, 2541-2550. [CrossRef] [PubMed] 